\section{Pine Bark Physical Characteristics Influence Pour-through Nitrogen Concentrations}

\author{
Alex X. Niemiera ${ }^{1}$ \\ Department of Horticulture, Virginia Polytechnic Institute and State University, \\ Blacksburg, VA 24061-0327
}

Ted E. Bilderback ${ }^{2}$

Department of Horticultural Science, Box 7609, North Carolina State University, Raleigh, NC 27695-7609

\author{
Carol E. Leda ${ }^{3}$ \\ Department of Horticulture, Virginia Polytechnic Institute and State University, \\ Blacksburg, VA 24061-0327
}

Additional index words. soil testing, fertilizer, container-grown, soilless media, sand

\begin{abstract}
Pine bark (PB), either unamended or amended with sand (S) at 9 PB: 1 S or 5 PB :1 S (v/v), was fertilized with solutions of 100,200 , or $300 \mathrm{mg}$ N/liter solution and tested for $N$ concentration using the pour-through method (PT). PB, 9 PB: $1 \mathrm{~S}$, and 5 PB: $1 \mathrm{~S}$ had porosities of $84 \%, 75 \%$, and $66 \%$, respectively. $\mathrm{PT} \mathrm{NO}_{3}-\mathrm{N}$ concentrations, obtained via

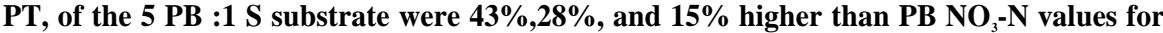
the 100,200 , and $300 \mathrm{mg}^{\circ}$ liter $^{-1}$ treatments, respectively. Differences in $\mathrm{N}$ concentration obtained with PT can be attributed to substrate physical characteristics. Based on the results, data for PT should be interpreted with regard to substrate porosity.
\end{abstract}

The pour-through method (PT), essentially a displacement method to sample the substrate solution of soilless media, has been shown to be a relatively quick and reliable technique of substrate analysis for container-grown plants (Yeager et al., 1983). Furthermore, N, P, and K concentrations and $\mathrm{pH}$ levels for PT used with a pine bark substrate have been shown to be highly correlated with levels of the saturated media extract method (Yeager et al., 1983). For nurseries in the eastern United States, pine bark is the most commonly used substrate for container-grown plants and is used unamended or amended with sand. Growers report that sand is incorporated to increase water-holding capacity and to add weight to the substrate to keep containers from falling over during windy conditions. Brown and Porkorny ( 1975) found that amending pine bark with sand decreased percolation rate and increased bulk density. However, there are no reports on how the altered substrate physical properties influence $\mathrm{N}$ concentrations for $\mathrm{PT}$, which is an important aspect because the bark : sand ratio varies considerably between growers. The objective of this experiment was to determine how amending pine bark with sand influences the $\mathrm{N}$ concentration for $\mathrm{PT}$.

Received for publication 9 July 1993. Accepted for publication 14 Jan. 1994. The cost of publishing this paper was defrayed in part by the payment of page charges. Under postal regulations, this paper therefore must be hereby marked advertisement solely to indicate this fact.

'Assistant Professor,

${ }^{2}$ Professor.

${ }^{3}$ Research Technician.
Materials and Methods

Dolomitic limestone $\left(3 \mathrm{~kg} \cdot \mathrm{m}^{-3}\right)$-amended pine bark $(\mathrm{PB})$ was amended with sand $(\mathrm{S})$ at ratios of $9 \mathrm{~PB}: 1 \mathrm{~S}$ or $5 \mathrm{~PB}: 1 \mathrm{~S}(\mathrm{v} / \mathrm{v})$; unamended bark served as a control. Substrates were analyzed for particle size, drainage volume, solids percentage, total porosity (TP), air space (AS), container capacity (CC), available (AW) and unavailable water (UW) at $1.5 \mathrm{MPa}$ tension, and bulk density (BD) at the Horticultural Substrates Laboratory, Dept. of Horticultural Science, North Carolina State Univ., Raleigh. Substrate analysis was conducted using five aluminum cylinders (volume $=347.5 \mathrm{~cm}^{3}$, diameter $=7.6 \mathrm{~cm}$, height $=7.6 \mathrm{~cm}$ ) per substrate, using packing procedures described by Bilderback et al. (1982). Separate substrate samples were used to determine water retention using procedures of Milks et al. (1989).

To determine TP, AW, UW, and AS for each substrate, a base plate was attached to each aluminum cylinder. This base plate consisted of an inner and outer plate with eight holes in each plate. Plates were fitted together as one unit to rotate so that holes could be aligned in the open position to allow drainage through plates or rotated in the opposite direction to a closed position to prevent any seepage of water through plates. Each unit (cylinder with attached base plate) was placed in a Buchner funnel that had been modified to accept the unit into a fixed position where the outside plate would not move. Rubber stoppers were inserted into the bottom of funnels. Units were rotated into the open position, and distilled water was added between cylinder and funnel walls to move through the base plate. Water was added slowly in a step-wise fashion to prevent air entrapment, as outlined in Karlovich and Fonteno (1986). Water level was eventually brought to the top of the substrate and allowed to equilibrate for $15 \mathrm{~min}$. The base plate was then closed by carefully rotating the unit with no disturbance to cylinder contents. Rubber stoppers were removed, and water from around the units was allowed to drain. A graduated cylinder was placed under each funnel, and the base plate was opened and the sample allowed to drain for 60 min. After drainage, the units were removed from the funnels, and the base plates were detached from cylinders. Wet weights of the samples were recorded. Samples were placed in a forced-air drying oven at $110 \mathrm{C}$ for $24 \mathrm{~h}$, and dry weight was recorded. Container capacity (percent volume) was defined as (wet weight - oven dry weight)/volume. Air space was the volume of water drained from the sample/volume of sample. Total porosity was $\mathrm{CC}+\mathrm{AS}$. An estimate of UW water was defined as the amount of water held at 1.5 $\mathrm{MPa}$. Using pressure plate extraction and procedures of Milks et al. (1989), available water was determined for each sample as CC - UW. Substrate physical characteristics data were subjected to analysis of variance (ANOVA) (SAS) and mean separation at $P \leq 0.5$ using the Wailer-Duncan $\mathrm{k}$ ratio $t$ test $(\mathrm{k}$ ratio $=100)$.

About 3.5 liters of each substrate type was added to a 3.8-liter plastic container, set on a metal mesh bench in a glasshouse, and irrigated with a breaker-equipped hose to initially settle bark. Container height and diameter were 17 and $15 \mathrm{~cm}$, respectively. For 4 weeks, $\approx 850 \mathrm{ml}$ of either 100,200 , and $300 \mathrm{mg} \mathrm{N} / \mathrm{liter}$ was applied to each container (all substrate treatments) on Monday, Wednesday, and Friday with a water breaker-equipped hose in concert with a fertilizer proportioner (venturi principle). This relatively large application volume (applied to all substrates) resulted in considerable leaching, which minimized salt accumulation in the substrate. Nitrogen source was a soluble dry fertilizer (Peters Potash Special, 20N-2.1P-24.9K, Grace-Sierra, Fogelsville, $\mathrm{Pa}$.) with $\mathrm{N}$ in the form of $\mathrm{NO}_{3}-\mathrm{N}$ (8.8\%), $\mathrm{NH}_{4}-\mathrm{N}(1.0 \%)$, and urea(10.2\%). After the third and fourth weeks of fertilization, substrate solutions were obtained $1 \mathrm{~h}$ following irrigation using PT in which each container was placed into a shallow collection tray and $100 \mathrm{ml}$ tap water, containing $5 \mathrm{mg}$ Fe/liter as FeEDTA, was applied to the bark's surface. Iron chelate is relatively stable and noninteractive with other cations (Norvell, 1972) in the $\mathrm{pH}$ of this substrate (5.2); chelate was used as a tracer to determine the degree of channeling of the applied solution from the substrate. Polyvinyl chloride rings were placed between container bottom and tray to prevent substrate from interacting with the collected solution. PT solution (leachate) volume was measured and analyzed for $\mathrm{NH}_{4}-\mathrm{N}$ and $\mathrm{NO}_{3}-\mathrm{N}$ using ionselective electrodes. The Fe concentration was analyzed using an atomic absorption spectrophotometer. The experiment was conducted twice in a factorial arrangement (three substrates $\times$ three $\mathrm{N}$ concentrations); because re- 
suits of both experiments were very similar, only data from the second experiment are shown. Containers were arranged in a randomized complete-block design-with one container per treatment in each of six blocks. Nutrient concentrations and volumes of solution collected with PT were subjected to ANOVA (SAS).

\section{Results and Discussion}

Relative to $100 \%$ pine bark, amending pine bark with sand resulted in decreased TP, drainage, AS, and UW; increased solids, AW, BD, and the proportion (by weight) of the smaller particle sizes; and container capacity was unaffected (Tables 1 and 2). Brown and Porkorny (1975) also showed similar findings regarding $\mathrm{BD}$, and proportion of smaller particle sizes. Of interest and previously unreported was the finding that $\mathrm{CC}$ values were the same for $\mathrm{PB}$ and sand-amended PB; however, PB had 9\% less AW (absolute basis) than 5 PB : $1 \mathrm{~S}$. Apparently, the addition of sand created micropores that held water less strongly than the surface and intraparticle water adsorption sites of PB.

Data for PT for the third and fourth week of fertilization were similar, and therefore only data for week 3 will be presented and dis-

Table 1. Particle-size distribution of screened aged pine bark (PB), 9 PB :1 coarse sand (S) (v/v), and 5 PB :1 S (v/v) substrates. ${ }^{2}$

\begin{tabular}{|c|c|c|c|c|}
\hline \multirow{2}{*}{$\begin{array}{l}\text { NBS } \\
\text { sieve \# }\end{array}$} & \multirow{2}{*}{$\begin{array}{c}\text { Sieve } \\
\text { opening } \\
(\mathrm{mm})\end{array}$} & \multicolumn{3}{|c|}{$\begin{array}{c}\text { Particle distribution in substrates } \\
\text { (\% wt of sample collected on each screen) }\end{array}$} \\
\hline & & PB & $9 \mathrm{~PB}: 1 \mathrm{~S}$ & $5 \mathrm{~PB}: 1 \mathrm{~S}$ \\
\hline$\overline{0.25}$ & 6.40 & 10.7 & 5.1 & 2.5 \\
\hline 5 & 4.00 & 14.0 & 5.9 & 3.1 \\
\hline 7 & 2.80 & 11.7 & 7.1 & 4.8 \\
\hline 10 & 2.00 & 11.1 & 7.7 & 6.1 \\
\hline 14 & 1.40 & 9.5 & 7.7 & 5.3 \\
\hline 18 & 1.00 & 8.7 & 7.5 & 5.4 \\
\hline 25 & 0.71 & 9.4 & 10.0 & 8.3 \\
\hline 35 & 0.50 & 8.7 & 12.2 & 12.2 \\
\hline 45 & 0.36 & 5.5 & 11.8 & 14.2 \\
\hline 60 & 0.25 & 4.4 & 11.2 & 15.7 \\
\hline 80 & 0.18 & 2.4 & 6.0 & 9.9 \\
\hline 140 & 0.11 & 2.1 & 4.4 & 7.1 \\
\hline pan & 0.00 & 2.0 & 3.4 & 5.6 \\
\hline
\end{tabular}

${ }^{2}$ Each value represents the mean of five air-dried samples.

Table 2. Physical properties of substrates.'

\begin{tabular}{|c|c|c|c|c|c|c|c|c|}
\hline \multirow[b]{2}{*}{ Substrates } & Drainage & $\operatorname{olids}^{x}$ & $\begin{array}{l}\text { Total } \\
\text { orosity }^{\text {w }}\end{array}$ & $\begin{array}{c}\text { Air } \\
\text { pace }^{v}\end{array}$ & $\begin{array}{l}\text { Container } \\
\text { apacity }^{u}\end{array}$ & $\begin{array}{c}\text { Unavailable } \\
\text { water }^{\text {t }}\end{array}$ & $\begin{array}{c}\text { Available } \\
\text { water }^{s}\end{array}$ & \multirow{2}{*}{$\begin{array}{c}\text { Bulk } \\
\text { density }^{\mathrm{r}} \\
\text { (glee) }\end{array}$} \\
\hline & (ml) & & & & $(\% \mathrm{vol})$ & & & \\
\hline $\begin{array}{l}\mathrm{PB} \\
(\mathrm{ml})\end{array}$ & $70.4 \mathrm{a}$ & 16 & $84 a$ & $20 \mathrm{a}$ & $\begin{array}{r}64 \mathrm{a} \\
(221)\end{array}$ & $\begin{array}{r}39 \mathrm{a} \\
(137)\end{array}$ & $\begin{array}{c}24 \mathrm{c} \\
(83)\end{array}$ & $0.19 \mathrm{c}$ \\
\hline $\begin{array}{l}9 \mathrm{~PB}: 1 \mathrm{~S} \\
(\mathrm{ml})\end{array}$ & $39.2 \mathrm{~b}$ & 25 & $75 b$ & $11 \mathrm{~b}$ & $\begin{array}{l}64 \mathrm{a} \\
(222)\end{array}$ & $\begin{array}{l}37 \mathrm{~b} \\
(127)\end{array}$ & $\begin{array}{l}27 \mathrm{~b} \\
(95)\end{array}$ & $0.38 \mathrm{~b}$ \\
\hline $\begin{array}{l}5 \mathrm{~PB}: 1 \mathrm{~S} \\
(\mathrm{ml})\end{array}$ & $12.2 \mathrm{c}$ & 34 & $66 c$ & $3 c$ & $\begin{array}{c}63 \mathrm{a} \\
(218)\end{array}$ & $\begin{array}{l}29 \mathrm{c} \\
(102)\end{array}$ & $\begin{array}{r}33 a \\
(116)\end{array}$ & $0.69 \mathrm{a}$ \\
\hline
\end{tabular}

${ }^{2}$ Analysis performed using standard aluminum soil sampling cylinders $(7.6 \mathrm{~cm}$ id., $7.6 \mathrm{~cm}$ high). Mean separation in columns by Waller-Duncan $\mathrm{k}$ ratio $t$ test $(\mathrm{k}$ ratio $=100), P=0.05$. Each value represents the mean of five cylinders.

${ }^{y}$ Drainage $=$ amount (in milliliters) of water drained from each cylinder after saturation before container capacity was reached.

'Solids = total porosity -100 . Represents the total volume (in percentage) of solids in each substrate.

"Total porosity is equal to container capacity+ air space.

"Air space was the volume of water drained from the sample $\div$ volume of the sample.

"Container capacity was (wet weight - oven dry weight) $\div$ volume.

Percent volume at $1.5 \mathrm{MPa}$.

Calculated as the difference between container capacity and unavailable water.

'Grams per cubic centimeter after drying samples in a forced-air drying oven at $110 \mathrm{C}$ for $24 \mathrm{~h}$.
S particles were $\leq 0.5 \mathrm{~mm}$, whereas only $25.1 \%$ of the PB substrate particles were $\leq 0.5 \mathrm{~mm}$ (Table 1). Because hydraulic conductivity is directly related to pore size and geometry (Brady, 1974), the greater proportion of small pores of $5 \mathrm{~PB}: 1 \mathrm{~S}$ allowed for less percolation and more dispersion of the PT solution than PB (Ross, 1989). Evidence for this explanation was demonstrated when Fe chelate was added to $100 \mathrm{ml}$ PT solution. Iron concentration of PB was about four times higher than that of $5 \mathrm{~PB}: 1 \mathrm{~S}$, substantiating the greater degree of solution channeling through the more porous PB and a greater displacement effect in the sand-amended substrates (Tables 3 and 4). The substrate $\mathrm{x} \mathrm{N}$ treatment interaction for $\mathrm{Fe}$ (Table 3) was due to the relatively high $\mathrm{Fe}$ concentration found with the $300 \mathrm{mg} \mathrm{N} / \mathrm{liter}$ treatment for PB. We believe that this interaction is not of practical importance and maybe related to the occasional variable nature of micronutrient detection in a pine bark substrate (Leda, 1986). About 25\% more solution was displaced in $5 \mathrm{~PB}: 1 \mathrm{~S}$ than in PB PT volume (Tables 3 and 4), again indicating the greater displacement capacity of applying a liquid to a substrate with a greater bulk density.

Ammonium concentrations, as those for $\mathrm{NO}_{3}-\mathrm{N}$, were higher with increasing $\mathrm{N}$ concentration applied. In contrast to $\mathrm{NO}_{3}-\mathrm{N}$ concentration, a substrate $\times \mathrm{N}$ treatment interaction (Table 3) showed that $\mathrm{NH}_{4}-\mathrm{N}$ concentrations were higher for $\mathrm{PB}$ than for sand-amended $\mathrm{PB}$ at the high $\mathrm{N}$ treatment, in which $\mathrm{NH}_{4}-\mathrm{N}$ concentrations in PB increased (with increasing $\mathrm{N}$ application) at a greater rate (PB linear regression line slope $=0.28$ ) than in sandamended substrates (9 PB :1 S and 5 PB :1 S linear regression line slopes $=0.21$ ) $($ Table 4$)$. The reason for this interaction is not understood.

Because each substrate held the same volume of water after saturation and drainage (CC) (Table 2), the $\mathrm{NO}_{3}-\mathrm{N}$ concentration can also be interpreted on the basis of mechanisms that may affect $\mathrm{NO}_{3}-\mathrm{N}$ retention in each substrate. Pine bark held more UW and less AW than sand-containing substrates (Table 2). The high unavailable water content would be assumed to be tightly bound around bark particles and in vesicles inside bark particles even at low tensions, such as after drainage (0 kpa), despite the fact that percent volume of unavailable water was measured at a much higher tension (1.5 MPa). This bound water likely contained applied $\mathrm{NO}_{3}-\mathrm{N}$. A case for this can be inferred where $\mathrm{NO}_{3}-\mathrm{N}$ concentrations were higher for $5 \mathrm{~PB}: 1 \mathrm{~S}$ than $9 \mathrm{~PB}: 1 \mathrm{~S}$ as well as for PB.

These results can be interpreted to demonstrate that PT testing of a porous substrate will yield lower $\mathrm{N}$ concentrations than for a substrate amended with sand even when both substrate types receive the same fertilization. Thus, data obtained for PT must be interpreted in view of substrate porosity. The difference in $\mathrm{NO}_{3}-\mathrm{N}$ concentrations obtained with PT between substrates, regardless of $\mathrm{N}$ application concentration, are marginally significant in terms of the current interpretation of $\mathrm{N}$ suffi- 
Table 3. Standard error of means and sums of squares from analysis of variance for $\mathrm{NO}_{3}-\mathrm{N}, \mathrm{NH}_{4}-\mathrm{N}, \mathrm{Fe}$ $\left(\mathrm{mg} \cdot \operatorname{liter}^{-1}\right)$. and volume (in milliliters) obtained from PT after 3 weeks of $\mathrm{N}$ abdications.

\begin{tabular}{lccccc}
\hline & & \multicolumn{4}{c}{ Sums of squares } \\
\cline { 3 - 6 } Source & df & $\mathrm{NO}_{3}-\mathrm{N}$ & $\mathrm{NH}_{4}-\mathrm{N}$ & $\mathrm{Fe}$ & Volume \\
\hline Block & 5 & $293.5^{\text {Ns }}$ & $64.7^{\text {Ns }}$ & $0^{\text {Ns }}$ & $302.3^{\text {Ns }}$ \\
Substrate & 2 & $5261.8^{* * *}$ & $544.8^{* * *}$ & $4.6^{* * *}$ & $3075.1^{* * *}$ \\
N rate & 2 & $131266.6^{* * *}$ & $19738.0^{* * *}$ & $0.2^{*}$ & $459.4^{*}$ \\
Substrate $\times \mathrm{N}$ rate & 4 & $370.1^{\text {Ns }}$ & $369.1^{* *}$ & $0.3^{*}$ & $481.7^{\text {Ns }}$ \\
SE \pm & & 7.05 & 2.74 & 0.04 & 1.55 \\
\hline
\end{tabular}

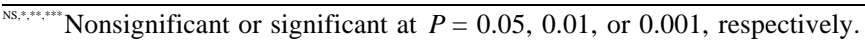

ciency or inadequacy. However, as research further defines substrate solution $\mathrm{N}$ adequacy concentrations and government regulations mandate reduced runoff, understanding how amending substrates affects physical characteristics and subsequent interpretation of PT analysis will become increasingly important.

\section{Literature Cited}

Bilderback, T.E., W.C. Fonteno, and D.R. Johnson. 1982. Physical properties of media composed of peanut hulls, pine bark and peatmoss and their effects on azalea growth. J. Amer. Soc. Hort. Sci. 107:522-525.

Brady, N.C. 1974. The nature and property of soils. 8th ed. Macmillan, New York.

Brown, E.F. and F.A. Porkorny. 1975. Physical and chemical properties of media composed of milled pine bark and sand. J. Amer. Soc. Hort. Sci. 100:119-121.

Karlovich, P.T. and W.C. Fonteno. 1986. Effect of soil moisture tension on the growth of chrysan- themum in three container media. J. Amer. Soc. Hort. Sci. 111:191-195.

Leda, C.E. 1986. Iron and manganese requirements of containerized plants grown in pine bark. MS Thesis, Virginia Polytechnic Inst. and State Univ., Blacksburg.

Milks, R.R., W.C. Fonteno, and R.A. Larson. 1989, Hydrology of horticultural substrates: II. Predicting physical properties of media in containers. J. Amer. Soc. Hort. Sci. 114:53-56.

Norvell, W.A. 1972. Equilibria of metal chelates in soil solution, p. 115-138. In: J.J. Mortvedt, P.M Giordano, and W.L. Lindsay (eds.). Micronutrients in agriculture. Soil Sci. Soc. Amer., Madison, Wis.

Ross, S. 1989. Soil processes: A systematic approach. Routledge, New York.

Wright, R.D. 1987. Nitrogen availability from urea in a pine bark medium. HortScience 22:70-72.

Yeager, T.H., R.D. Wright, and S.J. Donohue. 1983. Comparison of pour-through and saturated pine bark extract N, P, K, and pH levels. J. Amer. Soc. Hort. Sci. 108:112-114.
Table 4. Concentrations of $\mathrm{NO}_{3}-\mathrm{N}, \mathrm{NH}_{4}-\mathrm{N}$, and Fein solution and volume of solution collected at the end of the third week of $\mathrm{N}$ application of a PT test in which $100 \mathrm{ml}$ of tap water containing $5 \mathrm{mg} \mathrm{Fe} /$ liter had been applied to each substrate.

\begin{tabular}{|c|c|c|c|}
\hline \multirow[b]{2}{*}{ Substrate $^{z}$} & \multicolumn{3}{|c|}{$\mathrm{N}$ applied $\left(\mathrm{mg} \cdot\right.$ liter $\left.^{-1}\right)$} \\
\hline & 100 & 200 & 300 \\
\hline \multicolumn{4}{|c|}{$\mathrm{NO}_{3}-\mathrm{N}$ recovered (mg.liter ${ }^{-1}$ ) } \\
\hline PB & $46^{y}$ & 104 & 164 \\
\hline $9 \mathrm{~PB}: 1 \mathrm{~S}$ & 53 & 125 & 175 \\
\hline $5 \mathrm{~PB}: 1 \mathrm{~S}$ & 66 & 132 & 188 \\
\hline \multicolumn{4}{|c|}{$\mathrm{NH}_{4}-\mathrm{N}$ recovered (mg-liter ${ }^{-1}$ ) } \\
\hline PB & 10 & 32 & 65 \\
\hline $9 \mathrm{~PB}: 1 \mathrm{~S}$ & 8 & 27 & 50 \\
\hline $5 \mathrm{~PB}: 1 \mathrm{~S}$ & 9 & 27 & 52 \\
\hline \multicolumn{4}{|c|}{ Fe recovered (mg.liter ${ }^{-1}$ ) } \\
\hline PB & 0.87 & 0.66 & 0. \\
\hline $9 \mathrm{~PB}: 1 \mathrm{~S}$ & 0.47 & 0.26 & 0. \\
\hline $5 \mathrm{~PB}: 1 \mathrm{~S}$ & 0.17 & 0.14 & 0. \\
\hline \multicolumn{4}{|c|}{ Volume of solution recovered $(\mathrm{ml})$} \\
\hline PB & 61 & 69 & 56 \\
\hline $9 \mathrm{~PB}: 1 \mathrm{~S}$ & 72 & 69 & 68 \\
\hline $5 \mathrm{~PB}: 1 \mathrm{~S}$ & 75 & 86 & 80 \\
\hline
\end{tabular}

${ }^{2} \mathrm{~PB}=$ pine bark, $\mathrm{S}=$ sand. 